\section{Pain and laboratory animals}

SIR - The government's proposals to update the Cruelty to Animals Act 1876 (Nature 23 May, p.267) have been widely reported as tightening up the present deplorable situation, a view we strongly challenge.

On the question of pain, the government has proposed that the "severity" of an experiment should be balanced against its potential benefit. Three categories of severity are envisaged: mild, moderate and substantial. In addition, the government has set a "top severity limit" where "an animal which is in severe pain or distress which cannot be alleviated shall be immediately and painlessly killed".

Since it is impossible to devise a method of measuring pain in animals it follows that what may be considered "severe" pain or distress by one person may be dismissed as mild, moderate or substantial by another. Some government departments and officials share our view on this matter. For instance, the Home Office Departmental Committee of Inquiry on Experiments on Animals 1965 (the Littlewood Committee) concluded that "it is not as a rule possible to assess degrees of real pain in animals" (para. 187) and "it is often much more difficult to detect physical pain in an animal than in a human patient" (para. 174)

The subjective assessment of "severe" pain or distress renders such pain conditions meaningless to the animals, while at the same time allowing the government

\section{Romanian reactors}

SIR-We would like to provide some addi tional information on the Romanian nuc lear programme (Nature 2 May, p.4) There is nothing misleading, as you put it, about our references to two plants now under construction in Romania.

The reactor civil works are well advanced on the first three units, the main excavation for the fourth unit has been started and site clearing has been commenced for the fifth. The office building and some of the permanent service buildings have already been completed and partly occupied.

The cooling water intake pumping house is well advanced and the turbine foundations are reaching completion for the first and second units. The pipe fabrication shop, welder training and electrician shops are already in position.

In terms of manufacture, all the major orders have been placed. Babcock and Wilcox has already shipped heat exchangers and the first calandria or reactor vessel, the largest single component, is scheduled to be shipped from Canada before the end of this year. The arrangements between Atomic Energy of Canada Ltd (AECL) and the Romanians are that AECL will provide licence information so and experimenters to pretend that there are permissible levels of pain, and that animals are thereby protected against excessive suffering. Furthermore, how is the importance of the experiment to be defined and does this refer to therapeutic, commercial or scientific considerations? Take for example the LD50 test in which animals are deliberately poisoned to death, which is clearly one of the most painful animal experiments. On the basis of the government's proposals, LD50 would have to fulfil a really important need, since the test causes so much suffering. But LD50 is generally recognized as bad science, so would the government refuse to allow the test to be performed? Or would the "severity" of LD50s be redefined as "moderate" or "mild" to overcome these difficulties? The latter course seems highly probable since the government has stated that it will not prohibit the LD50 test.

But the idea of prohibiting experiments, such as the use of animals to gain manual dexterity, is already established in the Cruelty to Animals Act 1876 and could readily be extended to other types of experiments, as a positive step towards a completely ethical system of research and health care.

\section{Mobilisation for}

Laboratory Animals,

51 Harley Street,

London W1N 1DD, UK

ROBERT SHARPE

that the Romanians can undertake a significant amount of the work themselves on the subsequent units

The drawings and specifications have been delivered to the Romanians and they have a large engineering and drafting team of around $1,000 \mathrm{key}$ staff who are now fully familiar with the engineering details of the CANDU reactor.

The fuel manufacturing shops in Romania have been completed and fuel is being manufactured and stored.

Commitment to the programme is evident to the highest levels in Romania, and this was obvious at the recent visit of President Nicolae Ceausescu to Canada. It included a tour of the Gentilly CANDU Nuclear Power Plant during which $\mathrm{Mr}$ Ceausescu entered the containment building and inspected some of the components while the reactor was at full power. $\mathrm{He}$ also reviewed the Romanian plans to commit further units and stated that the site for the next five reactors would be chosen before the end of this year.

A.I. SMITH

Project Director, Cernavoda Atomic Energy of Canada Limited, CANDU Operations,

Sheridan Park Research Community,

Mississauga, Ontario L5K $1 B 1$,

Canada

\section{The nose knows}

SIR - Once again Gaylarde has taken it upon himself to "summarize briefly" my hypothesis (Nature 315, 92; 1985), and once again I must urge interested readers to read the original instead (Nature 311, $515 ; 1984)$. It is true that "the inhabitants of the dry desert regions of North Africa and the Middle East, where natural conditions provide the most viscous air to be found on Earth, are not noted for short notes with wide nostrils", but this is not evidence of a lack of effect from climate. People in hot dry places have had to adapt to dust, because hot dry places produce dust more easily and because hot dry air supports more dust. More properly, dry particles float in dry air while humid particles (humidity gained from humid air) sink. That is why people in dusty climates have dust-trapping noses.

Regarding the irrelevance of Gaylarde's advertised "familial virtue", I only wish to be clear that I do not claim familial virtue, or even personal virtue. I claim to have made an argument which is logical and empirically reasonable. Gaylard has decided that I am either a fascist or a would-be fascist (Nature 313, 425; 1985 and see also Nature 314, 398; 1985). I would prefer to hear his thoughts about my argument, but it seems that he will never calm down enough to get it straight.

Department of Anesthesiology, JOHN HARTUNG Downstate Medical Center. State University of New York, 450 Clarkson Avenue, Brooklyn, NY11203, USA

\section{Safety cabinets}

SIR - In commenting on the relevant advantages of Class I and Class II safety cabinets (20 June, p.626), R. P. Clark deals only with the containment of aerosols. Much of my 40-year professional career as a medical microbiologist has involved work with high-risk pathogens including smallpox, lassa fever and simian B virus, and I have used all three classes of cabinets for this work. My experience leads me to say that for any pathogen in which the risk to the operator arises mainly from needle-stick type of injuries, Class II cabinets afford a significantly higher level of protection than Class I simply because of the better visibility which they afford and the better ergonomic design which is possible for Class II cabinets.

In my view it would be irresponsible to work in a Class I cabinet if a Class II cabinet was available, for this type of work

K. MCCARTHY

University of Liverpool,

Department of Medical Microbiology,

Duncan Building,

Royal Liverpool Hospital,

Prescot Street, PO Box 147

Liverpool L69 $3 B X, U K$ 